\title{
INTEGRATIVE TRENDS IN GEOGRAPHY EDUCATION
}

\author{
DOI: https://doi.org/10.18509/GBP210609v \\ DOI: 37.035:911(497.2) \\ 37.043:911(497.2)
}

\author{
Maya Vasileva \\ Sofia University "St. Kliment Ohridski", Faculty of Geology and Geography, Bulgaria
}

\begin{abstract}
In recent decades, integration processes in science and social practice have remarkably attracted the attention of the scientific community and significantly influenced the style of thinking in various fields. These processes and trends are a fact that does not fuel controversy and denial. Unfortunately, however, the ways of their realization and the forms of their manifestation are not so indisputable. In this respect, there is still no unanimity and in the various areas of human activity this is the most difficult task to solve. Proponents of holistic, unifying, global, integrated learning, developed and tested more than once, saw in the integration processes of modernity new arguments in its favor. These objective processes served as a new stimulus for updating and deepening the theory of comprehensive (integrated) learning.

In what way do we interpret the influence of these processes in science on the selection and structuring of the curriculum for general education needs? What trends are observed now and to what extent are the forms they acquire appropriate? How is it interpreted in the modern pedagogical literature the so-called "program integration"? Is there a common opinion about the nature, meaning, functions and forms of integration trends in education? These are vital questions to which a constructive, principled and objective answer should be given in order to continuously raise the level of pedagogical science and teaching practice. It is unlikely that a single report could provide a comprehensive answer to all the above questions. In this sense, we limit ourselves here to their projection in the field of teaching geography. We refer to the ancillary state of the system of geographical education in Bulgaria, to the way it functions, to the didactic resources it handles.
\end{abstract}

Keywords: integrative trends in science, geography education, principles of education, interdisciplinary links

\section{INTRODUCTION}

not yet found its optimal development, although many attempts have been made in this regard. Such developments are extremely necessary in the context of private didactics, because on this basis a generalized option for the application of integrative learning in the modern school can be reached. In this regard, the author of the present study sets himself two main tasks: to classify the integrative links applicable in the teaching of geography; to outline possibilities for realization of methodological, interdisciplinary and intrasubject synthesis in the teaching of geography.

The very concept of "integration" has Latin origins and means uniting, connecting parts into one whole. In it, the essential aspects of the elements are united for the difference from the mechanical sum of things, which ultimately leads to a new qualitative definition of the system. 
There is a significant terminological difference in the interpretation of integration in the literature. Some define it as integrative tendencies, which are "increasingly emerging as specific ways to improve the structuring of educational content for didactic purposes in order to help learners to better understand the phenomena of reality [1], [2], [3]. Others pay biggest attention to the structural and functional integrative tendencies, which he calls "quantitative and qualitative integration" [13].

Many publications in the pedagogical press consider the integrated approach in different aspects [10], [11]. It is often interpreted as a means of systematization in the goals, content and organization of the educational process, in order to synthesize and summarize the knowledge, beliefs and behavior of students as a developed person. In other words, the integral approach is a dialectical approach because it realizes the effect of wholeness through the dialectic of the whole and the parts. The world exists systematically and integrally and the knowledge about it must be built through the synthesis of sciences and in the synthesis of the subjects in the educational system. Therefore, knowledge of the world encompasses the processes of integration and differentiation, which is also the methodological basis of the integrated approach. Therefore, the integrated approach is a means to stimulate the cognitive activity of students and master the unity of the world, to synthesize knowledge and turn it into beliefs and behavior, for the functioning of education as a system of goals, content and organization of the pedagogical process. After taking into account the specifics of educational and scientific knowledge in the educational process, a number of authors indicate three levels of synthesis in the application of the integrated approach - methodological, interdisciplinary and intradisciplinary. Each of these levels is precisely defined by place, functions, content and forms in the overall learning process.

The highest form of integration is methodological synthesis. It realizes the ultimate effect of integration - systematic knowledge of the world, versatility in the development of the student's personality. On the basis of the methodological synthesis the private scientific knowledge of the students is integrated and generalized to the degree of scientific concepts and categories, to worldview knowledge and beliefs, to the formation of integral qualities. The students' views on the materiality of the world, on its regularities, on the interrelation between nature and human society, etc. deepen. The realization of the methodological synthesis is possible with a special purposeful organization of the educational process as a whole. All subjects take part in its implementation through the worldview elements included in their content. Through it, general scientific conclusions, concepts and philosophical categories are formed - a system of views on the world. The theoretical formulations of the integrated approach find a wide echo in the methodology of teaching geography, as well as in the practice of the subject [5], [8], [12].

In geography education, the integrated approach is defined as "a system of activities (procedures, operations) related to its goals, content, organization and methodology, aimed at systematization, synthesis and summaries at different levels in horizontal (single classroom) and vertical plan (education from 5th to 12th grade), which leads to mastering the unity of the world and to the formation of the qualities of the multifaceted personality" [5]. According to the author of the present study, there is a difference between integration and the integrated approach.

Integration is an objective process, and the integrated approach is a means, a way of action on the part of the subject, with which he stimulates the integration processes. The in-depth analysis of the terminological diversity - integration, integrative tendencies, integral approach, shows that in their essence there is something common, unifying. It finds 
expression in the current setting for building the system of educational work in secondary school on the basis of integrative links, carried out at different levels. They find specific application in the teaching of all disciplines, in particular in the teaching of geography. Integrative links are the objectively existing form of interaction, of synthesis and generalization of knowledge, skills and worldview ideas, in which the latter are of a new quality [4], 12], [16]. They are a reflection of the objective links in the world around us, an intermediate link in the process of human interaction with the surrounding environment. This mediation is a result of the causal relationship between science and education, between the scientific and cognitive process.

The subject does not reflect science as a whole, but only its foundations in a reduced form [14], [15]. Scientific knowledge is a complete reflection of objective reality. In the process of interaction the subjects participate as a whole or through separate structural components related to their content. Therefore, it must be concluded that the use of integrative links in teaching geography aims not only at applying the acquired knowledge and skills from one subject to the acquisition of knowledge in another, but a functional synthesis of empirical knowledge that leads students to acquire knowledge, skills and the formation of worldview ideas on a new, higher level.

The issue of the types of integrative links has a certain practical and applied significance for the teaching of geography. Based on the analysis of their nature and the peculiarities of the training in the subject, the following classification can be accepted:

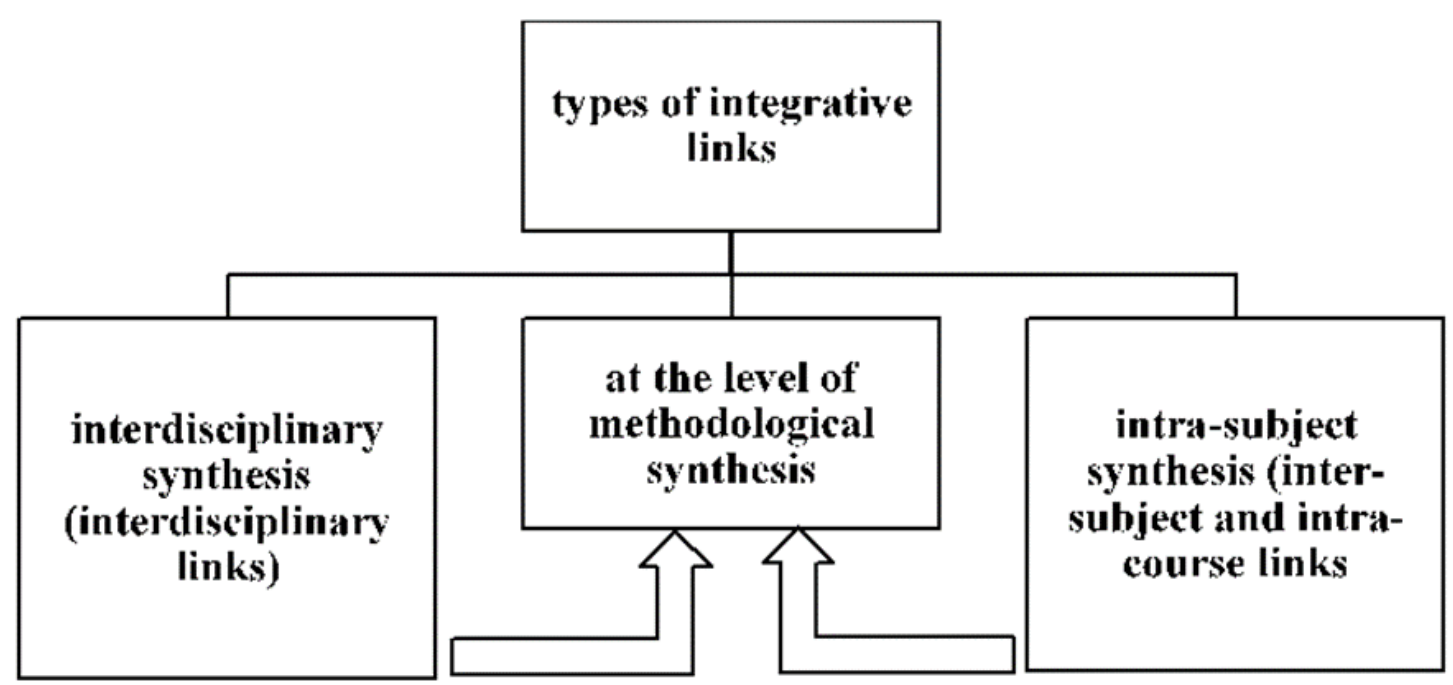

Figure 1. Classification of integrative links in geography education

In the practice of teaching geography, the interdisciplinary and intrasubject synthesis are successfully realized, ie. interdisciplinary, intrasubject and intracourse relations. Of interest are the views of Zverev and Maximova on the classification of interdisciplinary relations. It is proposed to group them in three directions: content-information; operationally effective; organizationally and methodologically, the latter being subordinated to the first two (Fig. 2). Their name shows that the interdisciplinary links of the third type enrich the methods, techniques and forms of organization of education. 

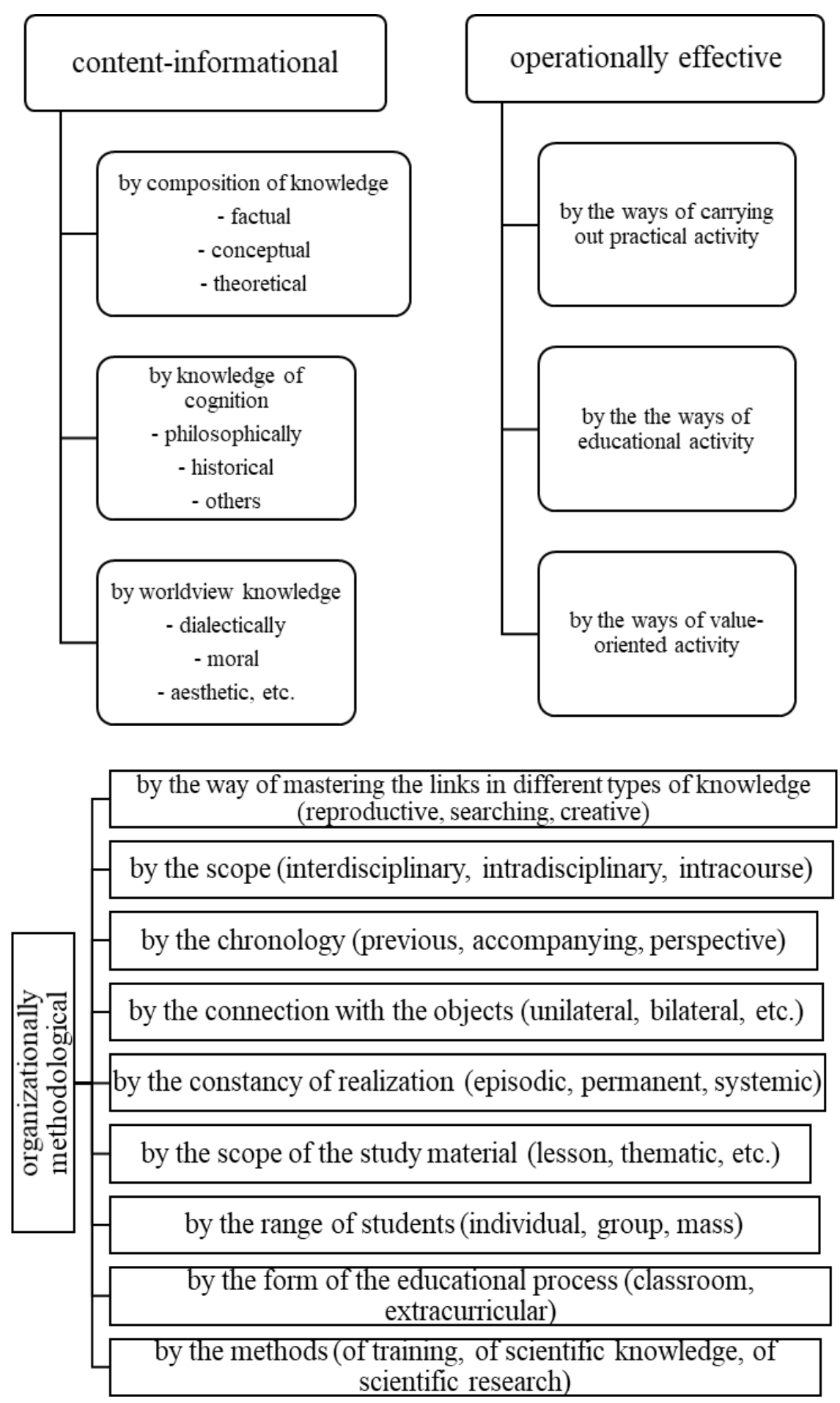

Figure 2. Classification of interdisciplinary links applicable in teaching geography [6]

The need to apply integrative links in the teaching of geography is based on deep methodological and scientific foundations. The integrative links in the teaching of geography are also imposed by the modern tendencies in the development of sciences and by the social practice. In this direction, the place of geography as a science with great integration potential can be seen. Proof of this is the very subject of her study - the natural and socio-economic territorial systems, their structure, dynamics and interaction in dialectical unity. Geography considers the geographical environment as a complex 
material system. It explores the territorial aspects of the interaction between human society and the natural environment on a local, regional and global scale. The borderline position of geography as a fundamental natural and social science determines its possibilities for interaction with both the social and natural sciences.

This reinforces the practical and applied importance of geography, '... its complexity is one of its most significant advantages over many other sciences in the integration of knowledge and the ability to solve interdisciplinary problems, not only purely geographical, but also those of other areas of knowledge" [9]. It can successfully participate in solving the ecological, raw material, demographic and food problem, in the rational territorial organization of production, etc. [7], [17]. Geography as a science reflects the diversity of its object (nature and society), but it is not able with its own means and methods to reveal the material unity of the world and the objective social reality. This is done through integrative processes with other sciences.

When it comes to using integrative links in the educational process, we should not confuse this form with integrated learning. These are two different concepts. This is about the implementation of integrative links in the following cases:

- when determining the goals and objectives of the educational process;

- in the educational content;

- in the organization and methodology of training

The issue related to defining the goals and tasks in the teaching of geography, in accordance with the modern formulations for the application of integrative links, acquires new dimensions. It is necessary, above all, to differentiate the main goal of the educational process between the different school levels. Secondly, each subject must make sense of and justify its contribution to the formation of integral knowledge, skills and beliefs in students.

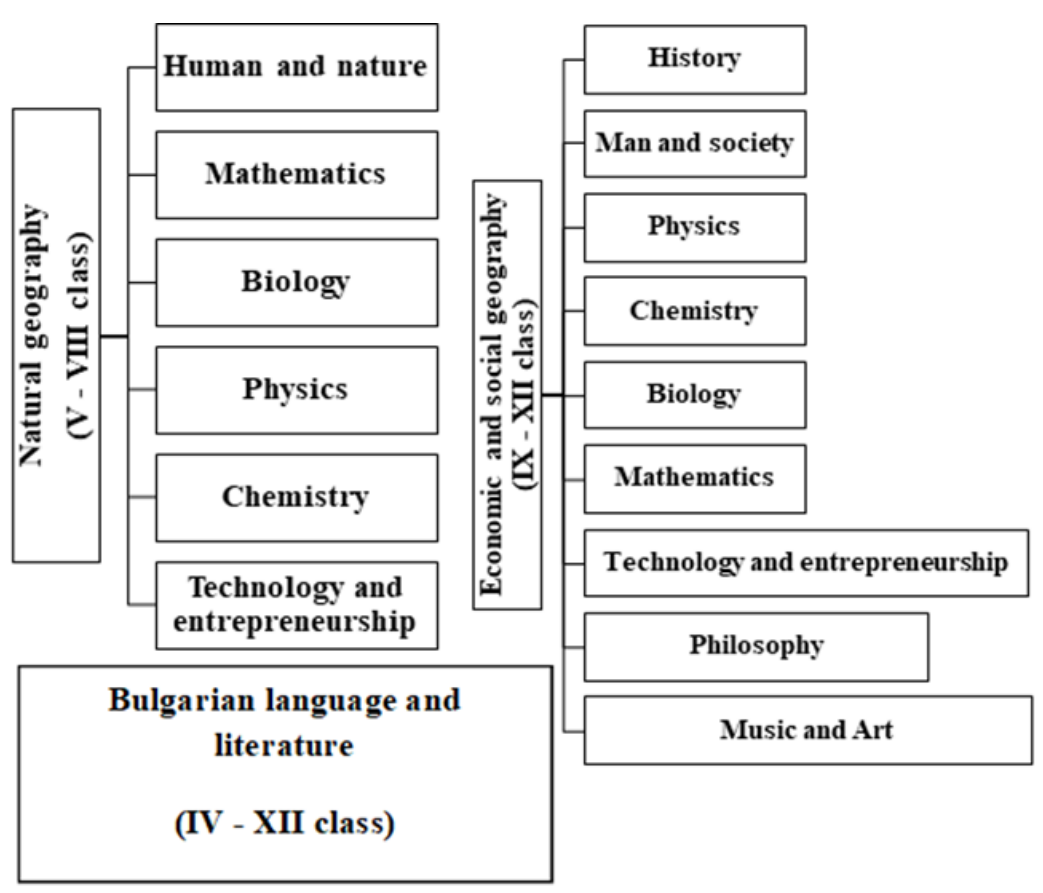

Figure 3. Interdisciplinary links in geography education

It can be seen from the figure that when studying the courses in natural geography it is expedient and possible to make a connection with the education in man and nature, 
mathematics, biology, physics, chemistry, technology and entrepreneurship, etc. At the heart of many natural geographical processes and phenomena are physical, chemical and biological laws and patterns. In this case, the interdisciplinary synthesis leads to general scientific conclusions and generalizations about the unity and diversity of animate and inanimate nature, to preserve the harmony between nature and human society, the ecological balance in nature and others.

In the courses in economic and social geography, the closest interdisciplinary links are made with history, philosophy and the world and personality, less often with physics, chemistry and biology. The acquisition of scientific knowledge about the socio-economic territorial systems of different rank (global, regional, regional) is directly related to taking into account the role of socio-historical, natural and demographic factors.

Given the logic of the geographical sciences, the intellectual and age characteristics of the students, the intra-subject and intra-course links and synthesis are correctly applied with regard to the structuring of the educational content (Fig. 4).

\begin{tabular}{|c|c|c|c|c|c|}
\hline \multicolumn{2}{|l|}{ Natural } & \multicolumn{2}{|l|}{ Iconomical } & \multicolumn{2}{|l|}{ Regional } \\
\hline \multicolumn{6}{|c|}{ Geography of Bulgaria (X and XII grade) } \\
\hline \multicolumn{3}{|c|}{$\begin{array}{l}\text { Economic and social geography of the } \\
\text { world (IX class) }\end{array}$} & \multicolumn{3}{|c|}{$\begin{array}{c}\text { Economic and social geography of the } \\
\text { countries (IX class) }\end{array}$} \\
\hline \multicolumn{6}{|c|}{ Basic course in general natural geography (VIII grade) } \\
\hline $\begin{array}{l}\text { Atmosphere } \\
\text { hnd climate }\end{array}$ & Hydrosphere & Lithosphere & $\begin{array}{l}\text { Soil } \\
\text { cover }\end{array}$ & Biosphere & $\begin{array}{l}\begin{array}{l}\text { Geographical } \\
\text { envelope }\end{array} \\
\text { nat }\end{array}$ \\
\hline \multirow{2}{*}{\multicolumn{2}{|c|}{$\begin{array}{l}\text { Selected questions from } \\
\text { general natural geography } \\
\text { (V grade) }\end{array}$}} & \multicolumn{2}{|c|}{$\begin{array}{l}\text { Geography of the } \\
\text { continents (VI class) }\end{array}$} & \multicolumn{2}{|c|}{$\begin{array}{l}\text { Geography of the } \\
\text { continents }\end{array}$} \\
\hline & & - & & (VII class) & \\
\hline
\end{tabular}

From the analysis of the figure it can be seen that in the teaching of geography a complex system of intra-subject and intra-course connections is realized, which are the basis of the content-logical structure of the subject. Without their consistent implementation in the learning process, the successful acquisition of scientific geographical knowledge is inconceivable. This is due to the complex nature of geography, combining natural science and socio-economic knowledge.

The following summary conclusions can be drawn:

- In the model of the curriculum in geography there are two blocks - V - VIII class with study mainly of natural geography and IX - XII class with predominant study of economic and social geography. This is determined by the logic of science and the learning process, as well as by the intellectual and age characteristics of the students. It can be seen that there are strong interdisciplinary links between the courses in natural and socio-economic geography. This is because the study of complex dynamic socio-economic systems of different ranks is possible only with a good knowledge of the natural-territorial systems that are the subject of natural geography. The integrative links between the two blocks are an adequate reflection of the objectively existing unity in the structure nature - man - production.

- There are pronounced intra-subject and intra-course links between V and VIII grade. In the general natural courses the geographical envelope is studied component by 
component and complex. Getting acquainted with the individual components is a necessary prerequisite for the development of natural-territorial complexes at different levels. The intra-course links and their continuation allow, on the basis of the system of general natural-geographical concepts and regularities on a planetary scale, to acquire knowledge about the continents, to form skills for their complex characterization. The intra-course synthesis in VIII grade should lead the students to private scientific conclusions and generalizations about the mutual connection and conditionality between the separate geospheres, allows to reveal the basic geographical regularities on theoretical level and their manifestation in the different geocomplexes, condition - maintaining the harmonious balance between them.

- Intra-subject and intra-course links and interactions in the courses in economic and social geography are realized on the basis of the deductive approach. In the first part of IX grade a system of general concepts of economic and political geography is built: national economy, world economy, international division of labor, integration between the countries, branches of material production and non-productive sphere, economic region and others. The private scientific conclusions and generalizations are connected with the leading ideas and regularities of the social development. This is a necessary theoretical basis for studying the regional shares - economic geography of the countries and economic geography of Bulgaria. Their study rediscovers and proves the general patterns in the development of the countries, while revealing the common and special in them.

The realization of integrative links at the level of modern requirements is connected first of all with the improvement of the methodology and the organization of the educational process in geography. First of all, there is a requirement for a new approach to planning the learning process. Undoubtedly, this issue has always been in the attention of teachers, but now it is necessary to specifically plan all kinds of integrative links in courses. This means to know in advance very well the interdisciplinary key problems in the directions and courses, the educational content in the related disciplines and the possibilities for establishing interdisciplinary links, as well as those for making interdisciplinary and intracourse links.

The problem of the realization of integrative links is closely related to the qualitative characteristics of the educational documentation in general and in particular that of geography. It can definitely be said that the new textbooks in geography, both through the main text and through the non-textual components, create preconditions for the realization of interdisciplinary, intrasubject and intracourse links. In this regard, the methodological guidelines in the teacher's book are also helpful to the teacher.

The realization of integrative links at the level of modern requirements is related to a new approach in the organization and conduct of the educational process in geography. It does not deny the existing subject system, but only perfects it. The systematic realization of integrative links leads to new forms of education, the result of cooperation between teachers in different disciplines, e.g. integral lesson, integral seminar, complex discussion, complex excursion, etc. The integral lesson does not deny the main types of lessons, but develops them [12], [14], [15].

The various forms of education, which create an opportunity to apply knowledge and skills from different subjects, to private scientific conclusions and generalizations, allow to formulate and make sense of general scientific conclusions about nature, society, production, to form integral qualities in students. 
If various methods and techniques with integrative orientation are systematically applied, not only in the teaching of geography, but also in other subjects, the students naturally prepare for the performance of tests on an integral basis. In this way, the knowledge in several subjects, the skills of the students to transfer knowledge and the way of mental activity from one subject to acquire knowledge or reveal regularities in another are checked and evaluated. Eg. The topic "Problems of the interaction between nature and society" allows to test the knowledge of geography, biology and chemistry.

The realization of integrative links in the teaching of geography needs to be done on the basis of problem-based learning in order to develop the cognitive activity of students and their creative thinking. This implies reproductive activity on an integral basis (reproduction of knowledge from other subjects by the teacher or students, discussion of private problems and solving individual cognitive tasks), derivation of interdisciplinary learning problems and independent search for ways to solve them (by applying knowledge and the ways of mental activity in a familiar and creative learning situation).

\section{CONCLUSION}

In conclusion, the following conclusion can be made: The application of integrative links in the educational process in geography has a huge educational, upbringing and developmental impact. The problem of standing as a whole - general didactic and methodological, is very complex, so its study and research continues. The presented theoretical formulations are an addition to the creative research aimed at shedding light on the issues related to the integrative links in the teaching of geography.

Although the above affects the implementation of integrative links in the teaching of geography in Bulgaria, continuity can be sought at the European level. This is necessary given the fact that the country is part of the European educational space. In this regard, the research interest should be focused first - on the study of issues in didactics and methodology of teaching geography in European countries, second - on the delineation of commonalities and differences between European countries and Bulgaria, and third on the derivation of specific opportunities for stimulating the integrative connections in the teaching of geography in Bulgaria.

\section{REFERENCES}

[1] Андреев, М. Процесьт на обучението. Дидактика. УИ София, 1996

[2] Андреев, М. Предметна или комплексна система на обучение. НП, 1980, № 10

[3] Андреев, М. Някои актуални интерпретации на интегративните тенденции в обучението. НП, 1983, № 4

[4] Гайтанджиева, Р. Стратегия на географското образоваине в СОУ в новите реалности, Анубис, С. 2000

[5] Гайтанджиева, Р. Интегрален подход в обучението по география. В - Интегрален подход в обучението по география (идеи, проблеми, опит). С. МНП, 1984

[6] Зверьев, И. Д., В. Н. Максимова. Междупредметные связи в современной школе. М. Педагогика, 1981

[7] Златунова, Д. Оценка и картографиране на негативните последици за гр. Севлиево от наводнения, In Annuaire de l'universite de Sofia "St. Kliment Ohridski" Faculte de geologie et geographie. Livre 2 - GEOGRAPHIE, Tome 108, 2016, 117-137

[8] Маноилова, М. Интегралният подход в обучението по география. В - Известие на БГД, 22, 1984 
[9] Мишев, К. Нови идеи и тенденции в развитието на географската наука и тяхното отражение в програмите по география в училищата. В - Интензификация на обучението по география в съвременното училище, С. МНП, СНР, БГД, 1984

[10] Николов, П. Интегралният подход в педагогическия процес, С. НП, 1985

[11] Стаменов, И. Интегралният подход, НП. 1981, №5

[12] Цанкова, Л. Ръководство по дидактика на географията, УИ, С. 2005

[13] Ingram, I. B. Curriculum Integration and Lifelong Education. Oxford, 1979

[14] Reinfried, S. \& Haubrich, H. (Hrsg.). Geographie unterrichten lernen. Die Didaktik der Geographie. 1. Aufl. Berlin: Cornelsen. 2015

[15] Rinschede, G. Geographiedidaktik. 3. Aufl. Paderborn u.a.: Ferdinand Schöningh 2007

[16] Wasileva, M. Naydenov, K. Atanasov, D. Contemporary Trends in Geographical Education. In: Proceedings of the International conference "InterCarto/InterGIS". 2017.3 (23): pp. 205-210. 2017

[17] Zlatunova, D. Flood Risk Assessment - a Basis for Sustainable Spatial Development. Case study: the Republic of Bulgaria, In Progress in Water Geography - Pan - European discourses, methods and practices of Spatial Water Research. University of Tartu, 2014 